\title{
New Bulky Phosphino-Pyridine Ligands. Palladium and Nickel Complexes for the Catalytic Polymerization and Oligomerization of Ethylene
}

\author{
Hsin-Pei Chen, Yi-Hung Liu, Shie-Ming Peng, and Shiuh-Tzung Liu* \\ Department of Chemistry, National Taiwan University, Taipe, Taiwan 106, Republic of China
}

Received April 2, 2003

\begin{abstract}
Two bulky phosphino-pyridine ligands (6-mesityl-2-((diarylphosphino)methyl)pyridine, $\mathbf{P} \sim \mathbf{N}$ ) were successfully prepared by means of Suzuki coupling of mesitylboronic acid with 6-bromo-2-picoline followed by phosphinylation. These ligands readily form the palladium and nickel complexes upon treatment with (COD)PdMeCl and (DME) $\mathrm{NiBr}_{2}$, respectively. These $\mathbf{P} \sim \mathbf{N}$ chelating $\mathrm{Pd}(\mathrm{II})$ and $\mathrm{Ni}(\mathrm{II})$ complexes were characterized by both spectral data and X-ray crystallography. The coordination geometry around the metal center is square planar for the Pd(II) complexes and tetrahedral for the $\mathrm{Ni}(\mathrm{II})$ complexes. The cationic methylpalladium(II) complexes showed poor activity in the catalytic polymerization of ethylene, but the nickel complexes were highly active with the activation of MAO. The nickel complexes catalyzed the polymerization of ethylene with an $\mathrm{Al} / \mathrm{Ni}$ ratio of 150 , whereas diand trimerization was observed when the $\mathrm{Al} / \mathrm{Ni}$ ratio is 500 . The obtained polyethylenes are highly crystalline.
\end{abstract}

\section{Introduction}

Due to the different properties of the phosphorus and nitrogen donors, the study of phosphine-imine $(\mathbf{P} \sim \mathbf{N})$ ligands in coordination chemistry and catalysis has received much attention. ${ }^{1-10}$ Recently, we demonstrated that palladium complexes $\mathbf{1}$ (Chart 1) can stabilize

(1) (a) Dario, D.; Felice, F.; Giancarlo,Belletti, D.; Graiff, C.; Tiripicchio, A. Organometallics 2002, 21, 761. (b) Crociani, B.; Antonaroli, S.; Di Vona, M. L.; Li coccia, S. J . Organomet. Chem. 2001, 631, 117. (c) Polosukhin, A. I.; Bondarev, O. G.; Lyubimov, S. E.; Korostylev, A. V.; Lyssenko, K. A.; Davankov, V. A.; Gavrilov, K. N. Tetrahedron: Asymmetry 2001, 12, 2197. (d) Rüther, T.; Done, M. C.; Cavell, K. J .; Peacock, E. J .; Skelton, B. W.; White, A. H. Organometallics 2001, 20, 5522. (e) Green, M. J .; Cavell, K. J .; Edwards, P. G. J . Chem. Soc., Dalton Trans. 2000, 853. (f) Bachechi, F.; Burini, A.; Fontani, M.; Galassi, R.; Macchioni, A.; Pietroni, B.'R.; Zanello, P.; Zuccaccia, C. Inorg. Chim. Acta 2001, 323, 45.

(2) (a) Bhattacharyya, P.; Loza, M. L.; Parr, J .; Slawin, A. M. Z. J Chem. Soc., Dalton Trans. 1999, 2917. (b) Faller, J. W.; Mason, J .; Parr, J . J . Organomet. Chem. 2001, 626, 181. (d) Parr, J .; Slawin, A. M. Z. Inorg. Chim. Acta 2000, 303, 116. (e) Yang, H.; AlvarezGressier, M.; Lugan, N.; Mathieu, R. Organometallics 1997, 16, 1401. (f) van den Beuken, E. K.; Smeets, W. J .J .; Spek, A. L.; Feringa, B. L. Chem. Commun, 1998, 223. (g) Gsponer, A.; Schmid, T. M.; Consiglio, G. Helv. Chim. Acta 2001, 84, 2986 (h) Romeo, R.; Scolaro, L. M.; Plutino, M. R.; Romeo, A.; Nicolo, F.; Del Zotto, A. Eur. J . Inorg. Chem. 2002, 629.

(3) (a) Dahan, F.; Dyer, P. W.; Hanton, M. J .; ones, M.; Mingos, D. M. P.; White, A. J . P.; Williams, D. J .; Williamson, A.-M. Eur. J .Inorg. Chem. 2002, 732. (b) Deng, W.-P.; Hou, X.-L.; Dai, L.-X.; Dong, X.-W. Chem. Commun. 2000, 1483. (c) Yang, H.; Gao, H.; Angelici, R. Organometallics 2000, 19, 622. (d) Liu, X.; Mok, K. F.; Leung, P. H. Organometallics 2001, 20, 3918. (e) Mikoluk, M. D.; McDonald, R.; Cavell, R. G. Inorg. Chem. 1999, 38, 2791. (f) Manzano, B. R.; J alón, F. A.; Gómez-de la Torre, F.; López-Agenjo, A. M.; Rodriguez, A. M.; Mereiter, K.; Weissensteiner, W.; Sturm, T. Organometallics 2002, 21 , 789 and references therein.

(4) (a) Braunstein, P.; Naud, F.; Rettig, S. J. New J . Chem. 2001, 25, 32, (b) Sauthier, M.; Leca, F.; Toupet, L.; Réau, R. Organometallics 2002, 21, 1591. (c) Coleman, K. S.; Green, M. L. H.; Pascu, S. I.; Rees, N. H.; Cowley, A. R.; Rees, L. H. Dalton Trans. 2001, 3384 and references therein.

(5) References involving diimine ligands: (a) J ohnson, L. K.; Killian, C. M.; Brookhart, M. J . Am. Chem. Soc. 1995, 117, 6414. (b) Ittel, S. D.; J ohnson, L. K.; Brookhart, M. Chem. Rev. 2000, 100, 1169 and references therein

\section{Chart 1}<smiles>C/C=c1/c2ccccc2p([P+](C)(C)C)[R7]1(C)N(C)C</smiles>

1<smiles></smiles>

2<smiles>CCCCc1cccc(-c2c(C)cc(C)cc2C)n1</smiles>

3 4a $\mathrm{Ar}=$ Mes

4b $\mathrm{Ar}=0$-Tol various insertion intermediates such as $\mathrm{CO}$ and ol efins/ alkynes. ${ }^{10}$ However, complex $\mathbf{1}$ can only catalyze the diand trimerization of ethylene. ${ }^{11}$ In comparison with the complex $\mathbf{2}$ devel oped by Guan ${ }^{8}$ and $\mathbf{3}$ by Brookhart, ${ }^{9}$ the substituents on the $\mathbf{P} \sim \mathbf{N}$ donor in $\mathbf{1}$ are less bulky. This might be attributed to result in the oligomerization of ethylene. In a continuation of this work, we have

(6) For phenanthroline ligands: (a) Rix, F. C.; Brookhart, M.; White P. S. J . Am. Chem. Soc. 1996, 118, 4746. (b) Milani, B.; Scarel, A.; Mestroni, G.; Gladiali, S.; Taras, R.; Carfagna, C.; Mosca, L. Organometallics 2002, 21, 1323. (c) Sen, A.; J iang, Z. Macromolecules 1993, 26, 911 and references therein.

(7) Müller, G.; Klinga, M.; Osswald, P.; Leskela, M.; Rieger, B. Z. Naturforsch., B: Chem. Sci. 2002, 57, 803.

(8) Guan, Z. B.; Marshall, W. J. Organometallics 2002, 21, 3580.

(9) Daugulis, O.; Brookhart, M. Organometallics 2002, 21, 5926

(10) (a) Chen, Y.-C.; Chen, C.-L.; Chen, J .-T.; Liu, S.-T. Organome tallics 2001, 20, 1285. (b) Reddy, K. R.; Surekha, K.; Lee, G.-H.; Peng, S.-M.; Chen, J.-T.; Liu, S.-T. Organometallics 2000, 19, 2637 and references therein.

(11) Chen, J.-T.; Liu, S.-T.; Zhao, K.-Q. J . Chin. Chem. Soc. 2000, $47,279$. 
Scheme 1. Preparation of $\mathbf{P} \sim \mathbf{N}$ Ligands

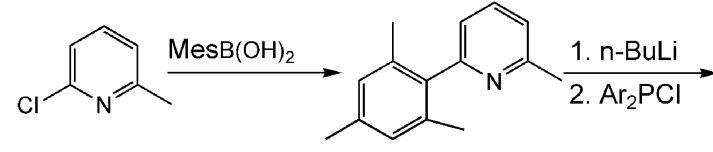

4a $\mathrm{Ar}=$ Mes $4 \mathrm{~b} \mathrm{Ar}=2-\mathrm{Tol}$

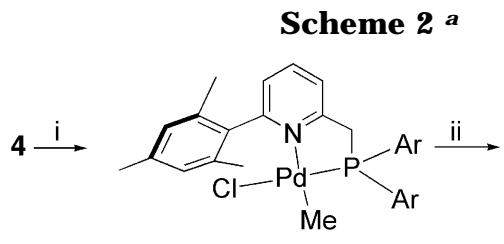

$5 \mathbf{a} \mathrm{Ar}=\mathrm{Mes}$ 5b $\mathrm{Ar}=2-\mathrm{Tol}$

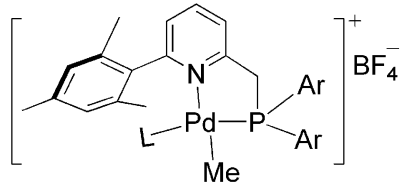

6a $\mathrm{Ar}=$ Mes, $\mathrm{L}=\mathrm{H}_{2} \mathrm{O}$ 6b $\mathrm{Ar}=2-\mathrm{Tol}, \mathrm{L}=\mathrm{CH}_{3} \mathrm{CN}$

a Legend: (i) (COD)PdMeCl, $\mathrm{CH}_{2} \mathrm{Cl}_{2}$, room temperature; (ii) $\mathrm{AgBF}_{4}, \mathrm{MeCN}$, room temperature.

designed new bulky $\mathbf{P} \sim \mathbf{N}$ ligands $\mathbf{4 a}-\mathbf{d}$ by introducing substituents at the 6-position of pyridine and a mesityl or tolyl group on the phosphorus atom. The two donors are linked by a nonenolizable rigid carbon framework. In this report, the synthesis of nickel and palladium complexes containing $\mathbf{4 a} \mathbf{a}, \mathbf{b}$ and the catalytic activities of these complexes in the polymerization and oligomerization of ethylene are described.

\section{Results and Discussion}

Preparation of Ligand and Complexes. Starting with chloropicoline, the mesityl group was introduced via a Suzuki coupling reaction to give 2-methyl-6mesitylpyridine, which was converted into the desired $\mathbf{P} \sim \mathbf{N}$ ligand by diarylphosphinylation at the $\alpha$-position (Scheme 1). Compound 4a was obtained as a white solid, whereas $\mathbf{4 b}$ is a viscous, air-sensitive liquid. ${ }^{31} \mathrm{P}$ NMR showed the chemical shifts for both ligands in the range of -20 to $-30 \mathrm{ppm}$, a typical range for diarylalkylphosphine. Other spectroscopic data are also consistent with the expected structure. Due to the air-sensitive nature of these two ligands, we were not able to obtain the analytically pure compounds, but the corresponding pal ladium compl exes were isolated upon the treatment of crude ligands with [(COD)PdMeCl] $(\mathrm{COD}=1,5$ cyclooctadiene).

The desired palladium complexes could be obtained quantitatively by the substitution reaction of (COD)$\mathrm{PdMeCl}$ with the corresponding ligand in dichloromethane at room temperature. Subsequent reaction of the complexes with $\mathrm{AgBF}_{4}$ in the presence of acetonitrile resulted in the formation of the cationic solvento palladium complexes $\left[(\mathbf{P} \sim \mathbf{N}) \mathrm{PdMeL}_{\mathrm{B}} \mathrm{BF}_{4}\right.$ (Scheme 2). However, the cationic palladium complex $\mathbf{6}$ a was obtained as an aqua complex, which presumably was due to the substitution of water during the recrystallization. All ${ }^{31 P}$ NMR signals of $\mathrm{Pd}(\mathrm{II})$ complexes are shifted

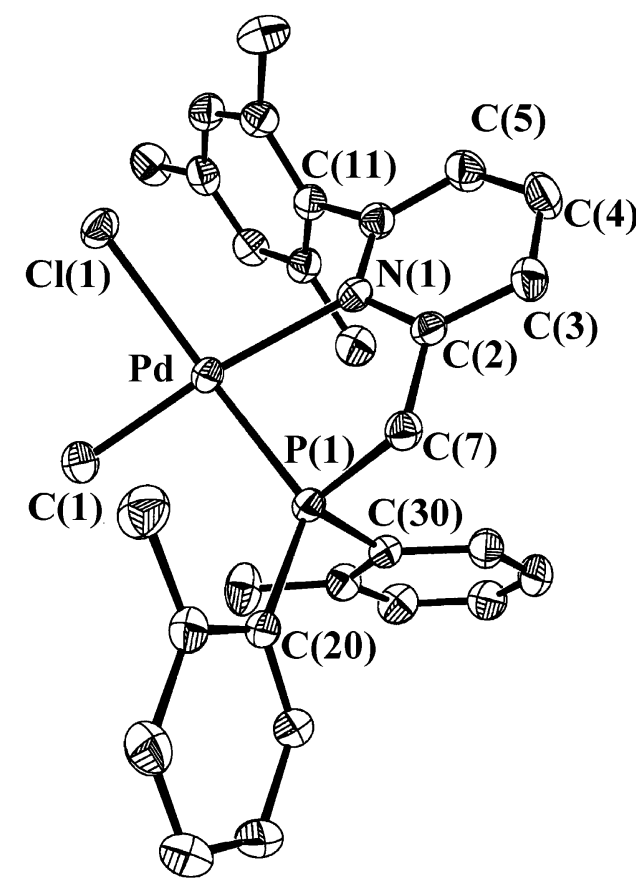

Figure 1. ORTEP plot of $\mathbf{5 b}$ ( $30 \%$ probability ellipsoids).

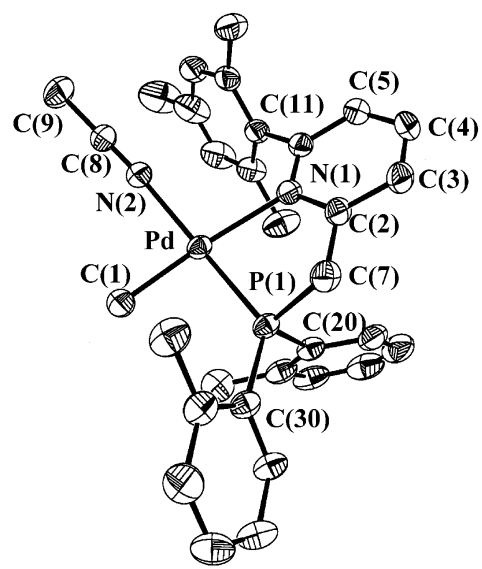

Figure 2. Molecular structure of the cationic part of $\mathbf{6 b}$ (30\% probability ellipsoids).

downfield relative to the free ligand, indicating the coordination of phosphine toward the metal center. As for the stereochemistry around the metal center, the small magnitude of the coupling constants J $\mathrm{P}-\mathrm{Me}$ $(2-4.5 \mathrm{~Hz})$ suggest that the methyl group is cis to the phosphine, which is in agreement with data for other complexes with the formula $(\mathbf{P} \sim \mathbf{N}) \mathrm{PdMeCl} .4 c, 9,10$ In addition to the spectroscopic analysis, the structures of complexes $\mathbf{5 b}$ and $\mathbf{6} \mathbf{a}, \mathbf{b}$ were further confirmed by their X-ray single-crystal structural determination (Figures 1 and 2; drawings for $\mathbf{6 a}$ are deposited as Supporting Information). Selected bond distances and bond angles of palladium and nickel complexes are collected in Tables 1 and 2, respectively. There are no significant differences observed in the bond lengths of $\mathrm{Pd}-\mathrm{P}(1), \mathrm{Pd}-\mathrm{N}(1)$, and $\mathrm{Pd}-\mathrm{C}(1)$ for $\mathbf{5 b}$ and $\mathbf{6 a}, \mathbf{b}$, which are also in agreement with the values for complex $\mathbf{3}$ and related species. ${ }^{7,9,10}$ The mesityl ring at the 2-position is seated nearly perpendicularly to the pyridine ring, as evidenced by the torsion angle $\mathrm{N}(1)-\mathrm{C}(6)-\mathrm{C}(11)-\mathrm{C}(12)\left(71.8^{\circ}\right.$ for $\mathbf{5 b}$; 
Table 1. Selected Bond Distances $(\AA)$ and Angles (deg) for $5 b, 6 a$, and $6 b$

\begin{tabular}{llll}
\hline & $5 b(X=C l(1))$ & $\mathbf{6 a}(X=0)$ & $\mathbf{6 b}(X=N(2))$ \\
\hline $\mathrm{Pd}-\mathrm{P}(1)$ & $2.2092(8)$ & $2.2045(9)$ & $2.216(1)$ \\
$\mathrm{Pd}-\mathrm{N}(1)$ & $2.226(3)$ & $2.212(3)$ & $2.224(3)$ \\
$\mathrm{Pd}-\mathrm{C}(1)$ & $2.043(4)$ & $2.030(4)$ & $2.027(4)$ \\
$\mathrm{Pd}-\mathrm{X}$ & $2.3760(8)$ & $2.166(3)$ & $2.083(3)$ \\
$\mathrm{N}(1)-\mathrm{C}(2)$ & $1.354(4)$ & $1.344(5)$ & $1.361(5)$ \\
$\mathrm{C}(2)-\mathrm{C}(7)$ & $1.499(4)$ & $1.505(5)$ & $1.512(6)$ \\
$\mathrm{C}(7)-\mathrm{P}(1)$ & $1.841(3)$ & $1.862(4)$ & $1.828(4)$ \\
$\mathrm{N}(1)-\mathrm{Pd}-\mathrm{P}(1)$ & $80.20(7)$ & $84.44(8)$ & $80.55(9)$ \\
$\mathrm{N}(1)-\mathrm{Pd}-\mathrm{C}(1)$ & $174.1(1)$ & $175.1(2)$ & $174.5(1)$ \\
$\mathrm{P}(1)-\mathrm{Pd}-\mathrm{C}(1)$ & $94.6(1)$ & $90.7(1)$ & $94.5(1)$ \\
$\mathrm{P}(1)-\mathrm{Pd}-\mathrm{X}$ & $162.77(3)$ & $102.0(1)$ & $174.8(1)$ \\
$\mathrm{P}(1)-\mathrm{C}(7)-\mathrm{C}(2)$ & $108.9(2)$ & $109.9(3)$ & $109.6(3)$ \\
$\mathrm{Pd}-\mathrm{P}(1)-\mathrm{C}(7)$ & $96.7(1)$ & $98.3(1)$ & $97.7(1)$
\end{tabular}

Table 2. Important Bond Distances $(\AA)$ and Angles (deg) for Nickel Complexes

\begin{tabular}{lll}
\hline & \multicolumn{1}{c}{$\mathbf{1 0 a}$} & \multicolumn{1}{c}{$\mathbf{1 0 b}$} \\
\hline $\mathrm{Ni}-\mathrm{P}(1)$ & $2.320(1)$ & $2.357(1)$ \\
$\mathrm{Ni}-\mathrm{N}(1)$ & $2.029(3)$ & $2.015(4)$ \\
$\mathrm{Ni}-\mathrm{Br}(1)$ & $2.3461(7)$ & $2.3887(8)$ \\
$\mathrm{Ni}-\mathrm{Br}(2)$ & $2.3458(7)$ & $2.3287(7)$ \\
$\mathrm{N}(1)-\mathrm{C}(2)$ & $1.362(4)$ & $1.345(6)$ \\
$\mathrm{C}(2)-\mathrm{C}(7)$ & $1.495(5)$ & $1.502(7)$ \\
$\mathrm{C}(7)-\mathrm{P}(1)$ & $1.831(4)$ & $1.848(5)$ \\
$\mathrm{N}(1)-\mathrm{Ni}(1)-\mathrm{P}(1)$ & $86.46(9)$ & $84.9(1)$ \\
$\mathrm{N}(1)-\mathrm{Ni}(1)-\mathrm{Br}(1)$ & $106.08(9)$ & $98.4(1)$ \\
$\mathrm{P}(1)-\mathrm{Ni}(1)-\mathrm{Br}(1)$ & $99.83(3)$ & $95.90(4)$ \\
$\mathrm{Br}(1)-\mathrm{Ni}(1)-\mathrm{Br}(2)$ & $125.5(3)$ & $115.01(3)$ \\
$\mathrm{N}(1)-\mathrm{Ni}(1)-\mathrm{Br}(2)$ & $120.47(9)$ & $134.0(1)$ \\
$\mathrm{P}(1)-\mathrm{Ni}(1)-\mathrm{Br}(2)$ & $112.45(3)$ & $119.76(4)$ \\
& &
\end{tabular}

$84.2^{\circ}$ for $\mathbf{6 a} ; 70.4^{\circ}$ for $\mathbf{6 b}$ ).In contrast to our previous findings, ${ }^{12}$ the bulky $\mathbf{P} \sim \mathbf{N}$ ligand $\mathbf{7}$ behaves as a monodentate ligand toward (COD)PdMeCl. Furthermore, $\mathrm{C}-\mathrm{H}$ activation takes place to form the $\mathrm{P} \sim \mathrm{N} \sim \mathrm{C}$ palladium complex $\mathbf{9}$ upon the reaction of $\mathbf{8}$ with silver tetrafluoroborate (Scheme 3).12 However, the $\mathbf{P} \sim \mathbf{N}$ ligands $(\mathbf{4 a}, \mathbf{b})$ behave as chelating bidentate ligands, because the aromatic ring of the bulky mesityl group is seated almost perpendicularly to the pyridine plane, which allows the metal ion to enter the ligand pocket.

For the nickel complexes, treatment of (DME) $\mathrm{NiBr}_{2}$ (DME $=1,2$-dimethoxyethane) with the corresponding ligand readily provided the dibromide species $[(\mathbf{P} \sim \mathbf{N})$ $\left.\mathrm{NiBr}_{2}\right](\mathbf{1 0 a}, \mathbf{P} \sim \mathbf{N}=\mathbf{4 a}$; 10b, $\mathbf{P} \sim \mathbf{N}=\mathbf{4 b})$. These complexes were isolated as brown solids and were soluble in most polar organic solvents. Unlike the palladium complexes, these nickel complexes are paramagnetic, suggesting that the nickel species have a tetrahedral geometry. The tetrahedral geometry was confirmed by X-ray single-crystal analysis. For the nickel species 10a (Figure 3) and 10b (drawings for 10b are deposited as Supporting Information), the geometries of both complexes are distorted tetrahedral, as evidenced by the bond angles around the metal center. In our previous study, the $\mathbf{P} \sim \mathbf{N}$ ligand in complex $\mathbf{1}$ can readily form the bis ligand complex $\mathbf{1 1},{ }^{13}$ suggesting that the bulky size of $\mathbf{4 a}, \mathbf{b}$ and $\mathbf{7}$ prevents complexation of more than one ligand per metal.

Polymerization. Complexes developed in this work were tested for polymerization of ethylene. However, the reaction of $\mathbf{6 a}$ or $\mathbf{6 b}$ with ethylene $\left(200 \mathrm{psi}, 30-60^{\circ} \mathrm{C}\right)$

(12) Chen, H.-P.; Liu, Y.-H.; Peng, S.-M.; Liu, S.-T. Dalton 2003, 1419

(13) Reddy, K. R.; Liu, S.-T. Unpublished results.

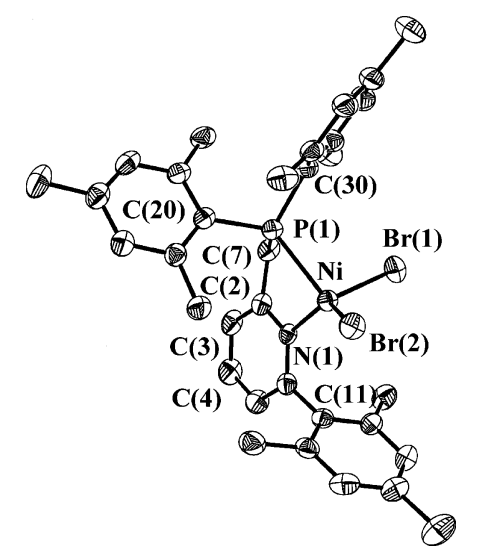

Figure 3. ORTEP plot of nickel complex 10a $(30 \%$ probability ellipsoids).

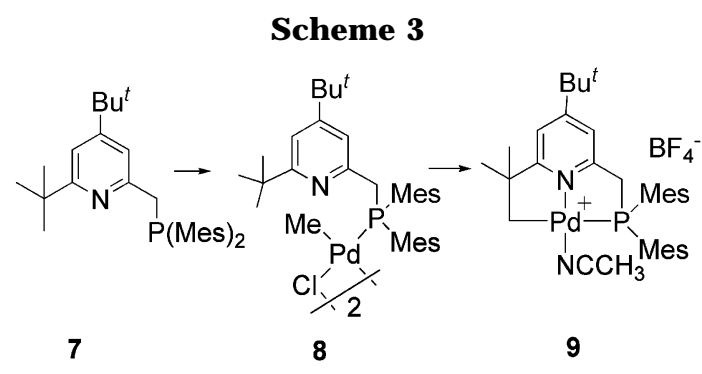

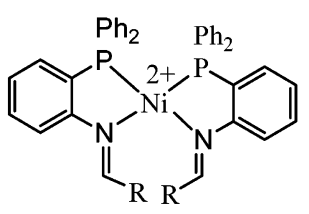

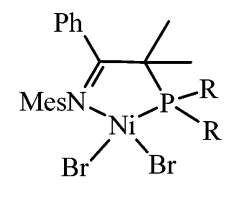

11

12a $\mathrm{R}=\mathrm{Ph}$

12b $\mathrm{R}=\mathrm{CH}_{3}$

gave negligible amounts of oligomers, which is different from the catalytic activity of $\mathbf{1 3}$ reported by Rieger and<smiles></smiles>

co-workers. ${ }^{7}$ In fact, palladium black was obtained in most instances, indicating the instability of these palladium complexes under the reaction conditions. To understand the relative migratory insertion of ethylene for the present system, equimolar amounts of $\mathbf{5 a}$ and $\mathrm{NaBAr}_{4}$ were dissolved in $0.5 \mathrm{~mL}$ of $\mathrm{CDCl}_{3}$ (with $5 \%$ $\mathrm{CD}_{3} \mathrm{CN}$ ) under an ethylene atmosphere. The relative intensity of $\mathrm{Pd}-\mathrm{CH}_{3}(5 \mathrm{a})$ in the ${ }^{1} \mathrm{H} \mathrm{NMR}$ spectrum disappeared very sl owly, accompanied by the formation of propene and palladium black. This might explain the different activities between $\mathbf{6 b}$ and $\mathbf{1 3}^{7}$

These activities are poor compared to those of the palladium complexes $\mathbf{2}$ and $\mathbf{3}$ developed by Guan ${ }^{8}$ and Brookhart, ${ }^{9}$ respectively. As addressed by Brookhart, the migratory insertion of ethylene into $\mathrm{Pd}-\mathrm{CH}_{3}$ is disfavored by the methyl group trans to the nitrogen donor in palladium complexes containing a $\mathbf{P} \sim \mathbf{N}$ type ligand due to the trans influence of that donor. ${ }^{9}$ This might explain the low activity of $\mathbf{6} \mathbf{a}, \mathbf{b}$ in polymerization. In addition, the space-filling model of $\mathbf{6 a}$ (Figure 4) 


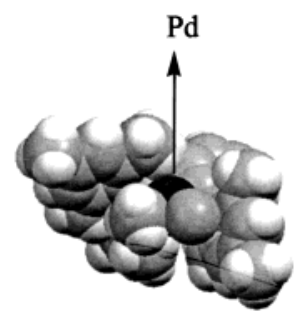

(a)

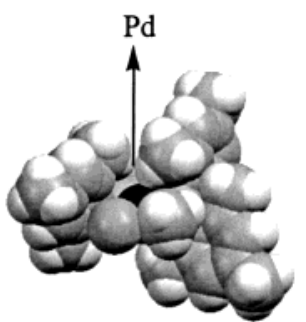

(b)
Figure 4. Space-filling model of palladium complex 6a: (a) top view; (b) bottom view.

Table 3. Polymerization of Ethylene Catalyzed by Nickel Complexes ${ }^{a}$

\begin{tabular}{|c|c|c|c|c|c|c|c|c|c|}
\hline \multirow[b]{2}{*}{ entry } & \multirow[b]{2}{*}{$\begin{array}{c}\mathrm{Al} / \\
\mathrm{Nib}\end{array}$} & \multirow[b]{2}{*}{$\begin{array}{l}\text { solv } \\
(\mathrm{mL})\end{array}$} & \multirow[b]{2}{*}{$\begin{array}{c}\mathrm{T} \\
\left({ }^{\circ} \mathrm{C}\right)\end{array}$} & \multicolumn{2}{|c|}{ insoluble PE ${ }^{d}$} & \multicolumn{4}{|c|}{ soluble $\mathrm{PE}^{\mathrm{e}}$} \\
\hline & & & & $\begin{array}{l}\text { yield } \\
(\mathrm{mg})\end{array}$ & $\begin{array}{c}\mathrm{T}_{\mathrm{m}} \\
\left({ }^{\circ} \mathrm{C}\right)\end{array}$ & $\begin{array}{l}\text { yield } \\
\text { (mg) }\end{array}$ & $M_{n}$ & $\mathrm{PDI}^{\mathrm{f}}$ & $\begin{array}{r}\mathrm{Br} / \\
1000\end{array}$ \\
\hline 1 & 150 & 50 & 30 & 1 & 15 & 39 & 4000 & 2.13 & \\
\hline 2 & & & & & & & & & \\
\hline 3 & 15 & 10 & 3 & & & 4 & & & \\
\hline $4^{\mathrm{h}}$ & & 5 & 30 & 670 & & 23 & & & \\
\hline $5^{i}$ & 15 & & 30 & & & 20 & 19 & 2. & 101 \\
\hline $6^{j}$ & & & 30 & 490 & 114.1 & 94 & 2300 & 2.25 & \\
\hline & & & $\mathrm{k}$ & 0 & & I & & & \\
\hline $8^{m}$ & 500 & 50 & 30 & 2010 & 110.2 & 71 & 3500 & 2.90 & 88 \\
\hline
\end{tabular}

a Conditions: complex 10a $(0.0115 \mathrm{mmol})$ in autoclave with ethylene (500 psi) for $4 \mathrm{~h}$. ${ }^{\mathrm{b}}$ Mole ratio $\mathrm{Al} / \mathrm{Ni}$. c Toluene as the solvent. ${ }^{d}$ PE obtained is in the solid form and is not soluble in most organic solvents and chlorinated benzenes. e PE obtained is soluble in toluene and most organic solvents. ${ }^{f} M_{w} / M_{n}$. ${ }^{g}$ Branching per $1000 \mathrm{C}$ determined by ${ }^{1} \mathrm{H}$ NMR spectroscopy. ${ }^{\mathrm{h}}$ Complex $10 \mathrm{a}$ $\left(5.8 \times 10^{-3} \mathrm{mmol}\right)$ as the catalyst. ${ }^{i}$ Complex $\mathbf{1 0 b}(0.0115 \mathrm{mmol})$ as the catalyst. ${ }^{j} \mathbf{4 a}+\mathrm{Ni}(\mathrm{acac})_{2}$ as the catalyst. ${ }^{k}$ Exothermic reaction. ' Butanes and hexenes. ${ }^{\mathrm{m}} \mathrm{CO}_{2}$ (850 psi) was added.

indicates that the metal center is readily accessible al ong the axis. Accordingly, the bulky substituents on either the pyridine ring or phosphorus appear not to interfere with the axial orientation of the palladium center.

The activity of nickel complexes in oligo- or polymerization of ethylene is quite different from that of the palladium species. With a molar ratio of MAO to complex of 150:1, complex 10a catalyzed the polymerization of ethylene to form PE in poor yields with a bimodal molecular weight distribution (Table 3). As shown in the table, all reactions gave a mixture of solid and lowmolecular-weight polyethylene. The obtained solid PE was insoluble in most organic solvents but was soluble in trichlorobenzenes. U pon heating in chlorobenzene, the obtained PE sample melted and formed a two-phase solution. $T_{m}$ values of all samples (Table 3 ) were in the range of $110-122^{\circ} \mathrm{C}$, which is typical for linear polyethylene. The XRD pattern of the solid PE from entry 3 shows that the sample has a highly orthorhombic structure (Figure 5a), with a molecular weight estimated by its viscosity in the range of $\sim 10^{6}$. In addition, the SEM of the sample (Figure $5 b$ ) is consistent with the observed diffraction pattern.

In addition to the solid product, there was a small amount of low-molecular-weight $\left(\mathrm{M}_{\mathrm{n}}=1900-4000\right)$ polyethylenes in the reaction mixture (Table 3 ). With the exception of entry 3 , these soluble PEs obtained in this work were slightly more branched than those polymers catalyzed by 12a reported by Brookhart and co-workers. ${ }^{9}$ However, we do not know whether these
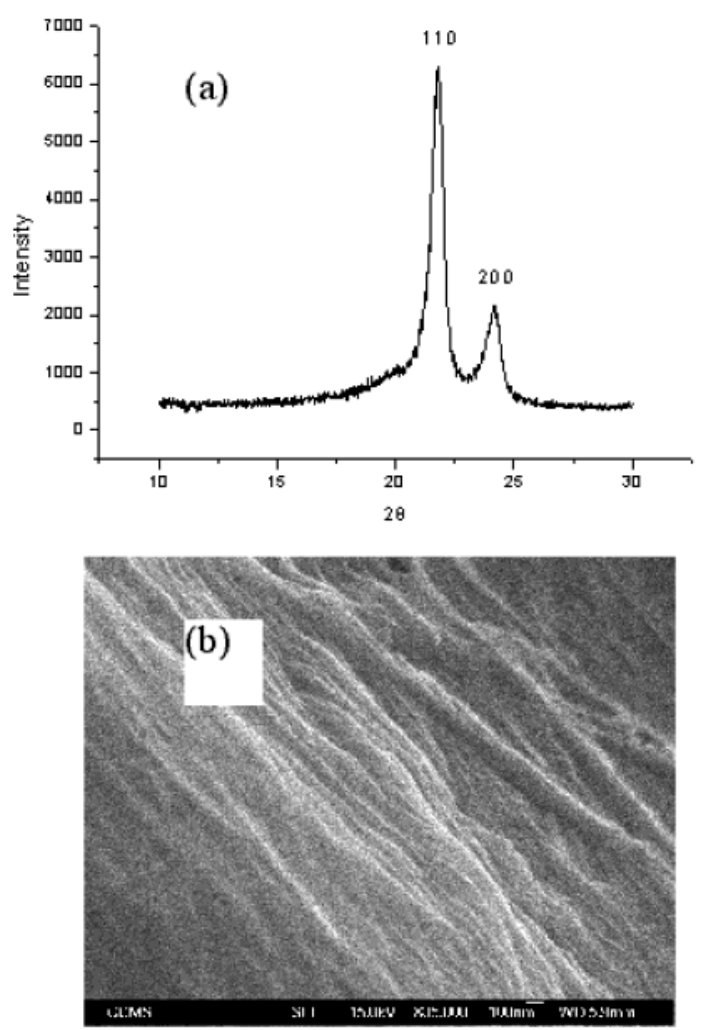

Figure 5. XRD pattern (a) and SEM photograph (b) of polyethylene.

two kinds of polyethylene are directed from the same active metal center or from two independent pathways at this moment.

Instead of polyethylene, butenes and hexenes were obtained in high conversions when a larger quantity of MAO ( $\mathrm{Al} / \mathrm{Ni}=500)$ was used (Table 3, entry 7$)$. It was illustrated by Brookhart's group that nickel complex 12b catalyzed the dimerization of ethylene with a high turnover frequency $\left(>10^{6}\right)$ in a very exothermic manner. ${ }^{9}$ In our investigation, the reaction was extremely exothermic as well, but the product formation was different from that obtained by complex 12b. Both butenes and hexenes were formed from these reaction conditions (see below). Another interesting observation about this catalysis was that a considerable amount of polymer was obtained by running the reaction in the presence of carbon dioxide under high-pressure conditions (Table 3, entry 8).

Di- and Trimerization. In an attempt to better understand the activity of nickel complexes in oligomerization, complex 10a and the mixture of $\mathbf{4 a}$ and $\mathrm{Ni}(\mathrm{acac})_{2}$ were used as precatalysts to study. The results are summarized in Table 4. All reactions were extremely exothermic, and the reaction temperature reached $70-80{ }^{\circ} \mathrm{C}$ even when the mixture was cooled with an ice bath. It was found that the nickel dibromide 10a had an activity similar to that of the nickel complex prepared in situ (entries 1 and 5), but with a slightly different product distribution. From entries 1, 3, and 4 (Table 4), it appears that a longer reaction time provides a better yield, indicating a substantial lifetime of the catalyst. Unlike the precatalyst $\mathbf{1 2} \mathbf{b},{ }^{9}$ the nickel complex with ligand $\mathbf{4 a}$ did provide the formation of hexenes with a negligible amount of oligomers. Reaction proceeded 
Table 4. Di- and Trimerization of Ethylene Catalyzed by Nickel Complexesa,b

\begin{tabular}{|c|c|c|c|c|c|c|c|c|}
\hline \multirow[b]{2}{*}{ entry } & \multirow[b]{2}{*}{$\mathrm{C}_{2} \mathrm{H}_{4}(\mathrm{psi})$} & \multirow[b]{2}{*}{$t(h)$} & \multicolumn{2}{|c|}{ butanes (g) } & \multicolumn{3}{|c|}{ hexenes (g) } & \multirow[b]{2}{*}{ TOFe $^{\mathrm{e}} \times 10^{5}$} \\
\hline & & & 1-butene & 2-butene & 1-hexene & 2-ethyl-1-butene & others $^{d}$ & \\
\hline 1 & 500 & 3 & 14.6 & 16.8 & 3.9 & 1.4 & 11.7 & 9.5 \\
\hline 2 & 300 & 3 & 4.6 & 9.7 & 0.9 & 0.6 & 2.9 & 3.6 \\
\hline 3 & 500 & 7 & 43.0 & 26.3 & 11.9 & 2.5 & 15.2 & 8.4 \\
\hline 4 & 500 & 10 & 53.6 & 28.9 & 18.5 & 1.8 & 10.9 & 6.0 \\
\hline $5^{f}$ & 500 & 3 & 18.8 & 8.4 & 1.9 & 1.3 & 8.2 & 4.8 \\
\hline 6 & 14.5 & 12 & 1.7 & 3.4 & 0 & 0.2 & & \\
\hline 79 & 500 & 3 & 0 & 0 & 0 & 0 & & \\
\hline
\end{tabular}

a Conditions: ligand $\mathbf{4 a}+\mathrm{Ni}(\text { acac })_{2}\left(1: 1\right.$ mole ratio) in toluene $(50 \mathrm{~mL})$ at $80{ }^{\circ} \mathrm{C}$. b Product analysis was based on ${ }^{1} \mathrm{H}$ NMR. ${ }^{\mathrm{C}} \mathrm{Cis}$ and trans forms. ${ }^{\mathrm{d}} 2$ - and 3-hexenes in both cis and trans forms. ${ }^{e}$ Overall turnover frequency $\left(\mathrm{C}_{4}+\mathrm{C}_{6}\right)$, in units of $\mathrm{g} \mathrm{mol}^{-1} \mathrm{~h}^{-1}$. ${ }^{\mathrm{f}} \mathbf{1 0 a}$ as the precatalyst. $9 \mathrm{Ni}(\mathrm{acac})_{2}$ as the catalyst.

selectively at atmospheric pressure of ethylene to yield butenes, but with lower turnover frequency (Table 4, entry 6).

For the product distribution, the butenes were the major component of the reactions with a $\mathrm{C} 4$ to $\mathrm{C} 6$ mole ratio of $\sim 3.5$. It appears that more butenes form under a lower pressure of ethylene (entries 1, 2, and 6), indicating that a higher concentration of ethylene favors the chain growth. All three isomeric forms (1-butene, cis- and trans-2-butene) of butenes were found and identified by their ${ }^{1 H}$ NMR spectroscopic data. In contrast, several isomeric forms of hexenes were obtained, including 1-, 2-, and 3-hexenes as well as 2-ethyl1-butene. The formation of these isomeric products is possibly due to the chain "walking" and/or metalcatalyzed isomerization. In agreement with this observation, these nickel complexes catalyze the isomerization of $\alpha$-olefins. The reaction of 1-hexene with $10 \mathrm{a}$ yiel ded 2- and 3-hexenes.

\section{Summary}

Pyridine-based bulky phosphine ligands and their palladium and nickel complexes were successfully prepared and characterized. The cationic methyl palladium(II) complexes showed poor activity toward ethylene, but the nickel(II) dibromo complexes were highly active in the presence of MAO. With a lower $\mathrm{Al} / \mathrm{Ni}$ ratio, the nickel complexes catalyzed the polymerization of ethylene, yielding an orthorhombic form. On the other hand, the same nickel species with a high $\mathrm{Al} / \mathrm{Ni}$ ratio shows a high activity in the catalysis of the di- and trimerization of ethylene.

\section{Experimental Section}

General Information. Nuclear magnetic resonance spectra were recorded in $\mathrm{CDCl}_{3}$ or acetone- $\mathrm{d}_{6}$ on either a Bruker $\mathrm{AC}-\mathrm{E}$ 200, AM-300, or AVANCE 400 spectrometer. Chemical shifts are given in parts per million relative to tetramethylsilane for ${ }^{1} \mathrm{H}$ and ${ }^{13} \mathrm{C} \mathrm{NMR}$ and relative $85 \% \mathrm{H}_{3} \mathrm{PO}_{4}$ for ${ }^{31} \mathrm{P} \mathrm{NMR}$. Infrared spectra were measured on a Nicolet Magna-IR 550 spectrometer (Series-II) as KBr pellets, unless otherwise noted. Gel permeation chromatography (GPC) data were obtained from a Waters Model 590 liquid chromatograph installed with a Lab Allience RI 2000 detector using THF as eluant at room temperature and polystyrene calibration curve for analyses.

All reactions, manipulations, and purification steps were performed under a dry nitrogen atmosphere. Tetrahydrofuran was distilled under nitrogen from sodium benzophenone ketyl. Dichloromethane and acetonitrile were dried with $\mathrm{CaH}_{2}$ and distilled under nitrogen. Other chemicals and solvents were of analytical grade and were used as received unless otherwise stated. Dimesitylchlorophosphine, ${ }^{14}$ (2,4,6-trimethylphenyl)- boronic acid, ${ }^{15} \mathrm{NiBr}_{2} \cdot \mathrm{DME}^{16}$ and (COD)PdMeCl ${ }^{17}$ were pre pared according to the procedures described in the literature.

2-Methyl-6-(2,4,6-trimethylphenyl)pyridine. A mixture of 2-chloro-6-methylpyridine $(2.5 \mathrm{~mL}, 22.75 \mathrm{mmol}),(2,4,6-$ trimethylphenyl)boronic acid $(4.44 \mathrm{~g} .27 .1 \mathrm{mmol})$, triphenyl phosphine $(0.6 \mathrm{~g}, 2.3 \mathrm{mmol}), \mathrm{Pd}(\mathrm{OAc})_{2}(0.127 \mathrm{~g}, 0.48 \mathrm{mmol})$, sodium bicarbonate $(8.5 \mathrm{~g}, 61.6 \mathrm{mmol})$, degassed water (30 $\mathrm{mL})$, and 1,2-dimethoxyethane $(25 \mathrm{~mL})$ in a $250 \mathrm{~mL}$ roundbottom flask was heated to reflux for $18 \mathrm{~h}$. The resulting reaction mixture was extracted with ethyl acetate $(50 \mathrm{~mL} \times$ 3). All extracts were combined, dried over $\mathrm{MgSO}_{4}$, and concentrated. The crude product was distilled under vacuum (bp $80{ }^{\circ} \mathrm{C}(0.1$ Torr)) to give the desired compound as a clear, col orless liquid (yield $4.12 \mathrm{~g}, 86 \%)$ : ${ }^{1} \mathrm{H}$ NMR ( $\mathrm{d}_{6}$-acetone, 400 $\mathrm{MHz}): \delta 7.71\left(\mathrm{dd}, \mathrm{J}=7.7,7.7 \mathrm{~Hz}, 1 \mathrm{H}, \mathrm{py} \mathrm{H}_{4}\right), 7.18(\mathrm{~d}, \mathrm{~J}=7.7$ $\mathrm{Hz}, 1 \mathrm{H}$, py $\left.\mathrm{H}_{3}\right), 7.03\left(\mathrm{~d}, \mathrm{~J}=7.7 \mathrm{~Hz}, 1 \mathrm{H}\right.$, py $\left.\mathrm{H}_{5}\right), 6.9$ (s, $2 \mathrm{H}, \mathrm{Ar}$ $\mathrm{H}), 2.50\left(\mathrm{~s}, 3 \mathrm{H}, \mathrm{CH}_{3}\right), 2.28\left(\mathrm{~s}, 3 \mathrm{H}, \mathrm{CH}_{3}\right), 1.96\left(\mathrm{~s}, 3 \mathrm{H}, \mathrm{CH}_{3}\right) .{ }^{13} \mathrm{C}$ NMR $\left(\mathrm{CDCl}_{3}, 100 \mathrm{MHz}\right): \delta 159.2,158.0,137.8,137.1,136.2$, 135.5, 128.2, 121.4, 120.8, $24.5\left(\mathrm{py}-\mathrm{CH}_{3}\right), 20.9,20.0$. HRFABMS $\left(\mathrm{C}_{15} \mathrm{H}_{17} \mathrm{~N}\right)$ : $\mathrm{m} / \mathrm{z}$ calcd, 211.1361; found, 212.1434 (M +1 ). Anal. Calcd for $\mathrm{C}_{15} \mathrm{H}_{17} \mathrm{~N}$ : C, 85.26; $\mathrm{H}, 8.11 ; \mathrm{N}, 6.63$. Found: C, 85.10; H, 8.13; N, 6.40.

2-[(Dimesitylphosphinyl)methyl]-6-(2,4,6-trimethylphenyl)pyridine (4a). To a solution of 2-methyl-6-(2,4,6trimethylphenyl)pyridine $(0.7 \mathrm{~g}, 3.3 \mathrm{mmol})$ in THF $(25 \mathrm{~mL})$ was added a $1.6 \mathrm{M}$ hexane solution of $\mathrm{n}$-butyllithium $(2.07 \mathrm{~mL}$, $3.3 \mathrm{mmol}$ ) at $-78{ }^{\circ} \mathrm{C}$. After the above reaction mixture was stirred for $3 \mathrm{~h}$, a THF solution (1.67 M) of dimesitylchlorophosphine $(2.09 \mathrm{~mL}, 3.3 \mathrm{mmol})$ was added. The resulting mixture was slowly warmed to room temperature and stirred for $12 \mathrm{~h}$. Water was added to quench the reaction. Upon concentration, the hexane extracts of the residue were passed through Cel ite to remove the insoluble materials. The filtrate was concentrated and chromatographed on silica gel using dichloromethane as el uant. The desired product was obtained as white solids upon concentration (yield $0.98 \mathrm{~g}, 62 \%$ ): $\mathrm{mp}$ 75-76 ${ }^{\circ} \mathrm{C} .{ }^{1} \mathrm{H}$ NMR $\left(\mathrm{d}_{6}\right.$-acetone, $\left.400 \mathrm{MHz}\right): \delta 7.53$ (dd, J = 7.7, $7.7 \mathrm{~Hz}, 1 \mathrm{H}$, py $\left.\mathrm{H}_{4}\right), 6.98\left(\mathrm{~d}, 1 \mathrm{H}, \mathrm{J}=7.7 \mathrm{~Hz}\right.$, py $\left.\mathrm{H}_{3}\right), 6.86$ $(\mathrm{s}, 2 \mathrm{H}, \mathrm{Ar} \mathrm{H}), 6.77\left(\mathrm{~d}, 1 \mathrm{H}, \mathrm{J}=7.7 \mathrm{~Hz}\right.$, py $\left.\mathrm{H}_{5}\right), 6.75(\mathrm{~d}, \mathrm{~J}=2.4$ $\mathrm{Hz}, 4 \mathrm{H}, \mathrm{Ar} \mathrm{H}), 4.11\left(\mathrm{~s}, 2 \mathrm{H}, \mathrm{py}-\mathrm{CH}_{2}\right), 2.26\left(\mathrm{~s}, 3 \mathrm{H}, \mathrm{Ar}-\mathrm{CH}_{3}\right)$, 2.18-2.17 (18H, $\left.\mathrm{Ar}-\mathrm{CH}_{3}\right), 1.88\left(\mathrm{~s}, 6 \mathrm{H}, \mathrm{Ar}-\mathrm{CH}_{3}\right) .{ }^{31} \mathrm{P} \mathrm{NMR}$ (161.9 MHz): $\delta-19.6$. HRFABMS: $\mathrm{m} / \mathrm{z}$ calcd for $\mathrm{C}_{33} \mathrm{H}_{38} \mathrm{NP}$, 479.2742; found, 479.2748 .

2-[(Di-o-tolylphosphinyl)methyl]-6-(2,4,6-tri methylphenyl)pyridine (4b). The procedure for the preparation of $\mathbf{4 b}$ is similar to that for $\mathbf{4 a}$. $\mathbf{4 b}$ was obtained as an air-sensitive yellow viscous liquid. ${ }^{1} \mathrm{H} \mathrm{NMR}\left(\mathrm{CDCl}_{3}, 200 \mathrm{MHz}\right): \delta 7.54$ (dd, J = 7.7, 7.7 Hz, $1 \mathrm{H}$, py $\left.\mathrm{H}_{4}\right), 7.47-7.40(\mathrm{~m}, 2 \mathrm{H}, \mathrm{Ar}-\mathrm{H})$, 7.28-7.21 (m, 7H, Ar-H), $7.03(\mathrm{~s}, 1 \mathrm{H}, \mathrm{Ar}-\mathrm{H}), 7.00-6.98(\mathrm{~m}$, $1 \mathrm{H}, \mathrm{Ar}-\mathrm{H}), 6.96(\mathrm{~s}, 2 \mathrm{H}, \mathrm{Ar}-\mathrm{H}), 3.69\left(\mathrm{~s}, 2 \mathrm{H}, \mathrm{py}-\mathrm{CH}_{2}\right), 2.36$

(14) Howthorne, M. F. J . Org. Chem. 1958, 23, 1579.

(15) Beswick, M. A.; Cromhout, N. L.; Harmer, C. N.; Palmer, J . S. Raithby, P. R.; Steiner, A.; Verhorevoort, K. L.; Wright, D. S. Chem. Commun. 1997, 583.

(16) Ward, L. G. L. I norg. Synth. 1971, 13, 154.

(17) Rülke, R. E.; Ernsting, J. M.; Spek, A. L.; Elsevier, C. J .; van Leeuwen, P. W. N. M.; Vrieze, K. Inorg. Chem. 1993, 32, 5769. 
Table 5. Selected Crystallographic Data of Complexes 5b, 6a, 6b, 10a, and 10b

\begin{tabular}{|c|c|c|c|c|c|}
\hline & $5 b$ & $6 \mathbf{a}$ & $6 \mathbf{b}$ & $10 a$ & 10b \\
\hline $\begin{array}{l}\text { formula } \\
\text { fw }\end{array}$ & $\begin{array}{l}\mathrm{C}_{30} \mathrm{H}_{33} \mathrm{CINPPd} \\
580.39\end{array}$ & $\begin{array}{l}\mathrm{C}_{34} \mathrm{H}_{41} \mathrm{BF}_{4} \mathrm{NOPPd} \\
703.86\end{array}$ & $\begin{array}{l}\mathrm{C}_{33} \mathrm{H}_{38} \mathrm{BCl}_{2} \mathrm{~F}_{4} \mathrm{~N}_{2} \mathrm{PPd} \\
757.73\end{array}$ & $\begin{array}{l}\mathrm{C}_{34.5} \mathrm{H}_{41} \mathrm{Br}_{2} \mathrm{Cl}_{3} \mathrm{NNiP} \\
825.53\end{array}$ & $\begin{array}{l}\mathrm{C}_{29} \mathrm{H}_{30} \mathrm{Br}_{2} \mathrm{NNiP} \\
642.04\end{array}$ \\
\hline cryst syst & monoclinic & monodinic & triclinic & monoclinic & monoclinic \\
\hline Space group & $\mathrm{P} 22_{1} / \mathrm{C}$ & $\mathrm{P} 22_{1} / \mathrm{n}$ & $\mathrm{P} \overline{1}$ & $\mathrm{P} 2 \mathrm{I} / \mathrm{n}$ & $\mathrm{P} 2{ }_{1} / \mathrm{C}$ \\
\hline$a, \AA$ & 20.1850(1) & 10.5380(1) & 12.5590(1) & 12.1420(1) & $17.4120(2)$ \\
\hline b, $\AA$ & $15.7450(2)$ & $25.3380(3)$ & $12.6630(2)$ & $23.9220(3)$ & $10.2430(1)$ \\
\hline c, $\AA$ & $8.6630(2)$ & $12.5570(1)$ & $13.2780(2)$ & 13.3490(1) & $16.2910(3)$ \\
\hline$\alpha$, deg & 90 & 90 & $83.092(1)$ & 90 & 90 \\
\hline$\beta$, deg & $90.178(1)$ & $92.428(1)$ & $61.840(1)$ & 106.777(1) & 106.735(1) \\
\hline$\gamma$, deg & 90 & 90 & $74.268(1)$ & 90 & 90 \\
\hline $\mathrm{V}, \AA^{3}$ & $2753.20(7)$ & 3349.86(6) & $1791.90(4)$ & 3712.32(6) & $2782.46(7)$ \\
\hline & 4 & 4 & 2 & 4 & 4 \\
\hline $\mathrm{D}_{\text {calcd, }}, \mathrm{Mg} / \mathrm{m}^{3}$ & 1.400 & 1.396 & 1.404 & 1.477 & 1.533 \\
\hline$F(000)$ & 1192 & 1446 & 772 & 1676 & 1296 \\
\hline cryst size, mm & $0.30 \times 0.25 \times 0.20$ & $0.25 \times 0.20 \times 0.10$ & $0.30 \times 0.25 \times 0.20$ & $0.20 \times 0.15 \times 0.15$ & $0.15 \times 0.10 \times 0.10$ \\
\hline$\theta$ range & $2.02-25.00$ & $2.09-25.00$ & $2.20-25.00$ & $2.63-25.00$ & $2.84-25.00$ \\
\hline no. of rflns collected & 16611 & 19581 & 11551 & 41428 & 20876 \\
\hline no. of indep rflns & $\begin{array}{c}4849\left(R_{\text {int }}=\right. \\
0.0286)\end{array}$ & $\begin{array}{c}5883\left(R_{\text {int }}=\right. \\
0.0354)\end{array}$ & $\begin{array}{c}6285\left(R_{\text {int }}=\right. \\
0.0193)\end{array}$ & $\begin{array}{c}6532\left(\mathrm{R}_{\text {int }}=\right. \\
0.0578)\end{array}$ & $\begin{array}{c}6373\left(\mathrm{R}_{\text {int }}=\right. \\
0.0544)\end{array}$ \\
\hline refinement method & \multicolumn{5}{|c|}{ full-matrix least squares on $\mathrm{F}^{2}$} \\
\hline $\mathrm{R}(\mathrm{I}>2 \sigma(\mathrm{I}))$ & $\begin{array}{l}R 1=0.0379 \\
w R 2=0.1052\end{array}$ & $\begin{array}{l}\mathrm{R} 1=0.0426 \\
\mathrm{WR} 2=0.1160\end{array}$ & $\begin{array}{l}\mathrm{R} 1=0.0467 \\
\mathrm{wR} 2=0.1567\end{array}$ & $\begin{array}{l}R 1=0.0504 \\
w R 2=0.1506\end{array}$ & $\begin{array}{l}R 1=0.0454 \\
w R 2=0.1049\end{array}$ \\
\hline goodness of fit on $\mathrm{F}^{2}$ & 1.172 & 1.097 & 1.278 & 1.033 & 1.017 \\
\hline
\end{tabular}

(s, 3H, $\left.\mathrm{Ar}-\mathrm{CH}_{3}\right), 2.30$ (s, 6H, $\left.\mathrm{Ar}-\mathrm{CH}_{3}\right), 2.01$ (s, 6H, $\mathrm{Ar}-\mathrm{CH}_{3}$ ). 31P NMR (161.9 MHz): $\delta$-29.6. HRFABMS: $\mathrm{m} / \mathrm{z}$ calcd for $\mathrm{C}_{29} \mathrm{H}_{30} \mathrm{PN}, 423.2116$; found, 423.2121.

Complex 5a. A mixture of $3 \mathbf{a}(0.355 \mathrm{~g}, 0.74 \mathrm{mmol})$ and (COD)PdMeCl $(0.19 \mathrm{~g}, 0.73 \mathrm{mmol})$ in dichloromethane $(10 \mathrm{~mL})$ was stirred for $2 \mathrm{~h}$ at ambient temperature. U pon concentration to a small vol ume of reaction mixture, hexane was added and the desired complex was precipitated out from the solution. The yellow solids were collected and washed with ether (yield $462 \mathrm{mg}, 98 \%$ ): $\mathrm{mp} 196-197{ }^{\circ} \mathrm{C}$ dec. ${ }^{1} \mathrm{H} \mathrm{NMR}\left(\mathrm{CDCl}_{3}\right.$, $400 \mathrm{MHz}$ ): $\delta 7.51$ (dd, J = 7.7, 7.7 Hz, $1 \mathrm{H}$, py H $\left.\mathrm{H}_{4}\right), 6.97-6.95$ (m, 2H, py H $\left.\mathrm{H}_{3,5}\right), 6.89$ (s, 2H, Ar H) , 6.78 (s, 4H, Ar H) , 4.50 (d, $\left.\mathrm{J}=10.4 \mathrm{~Hz}, 2 \mathrm{H}, \mathrm{CH}_{2}\right), 2.49\left(\mathrm{~s}, 12 \mathrm{H}, \mathrm{Ar}-\mathrm{CH}_{3}\right), 2.31(\mathrm{~s}, 3 \mathrm{H}$, $\left.\mathrm{Ar}-\mathrm{CH}_{3}\right), 2.18\left(\mathrm{~s}, 6 \mathrm{H}, \mathrm{Ar}-\mathrm{CH}_{3}\right), 1.99\left(\mathrm{~s}, 6 \mathrm{H}, \mathrm{Ar}-\mathrm{CH}_{3}\right), 0.69$ $\left(\mathrm{d}, \mathrm{J}=4.4 \mathrm{~Hz}, 3 \mathrm{H}, \mathrm{PdCH}_{3}\right)$. ${ }^{31} \mathrm{P} \mathrm{NMR}(161.9 \mathrm{MHz}): \delta 13.3$. ${ }^{13} \mathrm{C} \mathrm{NMR}\left(\mathrm{CDCl}_{3}, 100 \mathrm{MHz}\right): \delta 163.4,158.3,141.6(\mathrm{~d}, \mathrm{~J}=8.9$ $\mathrm{Hz}), 140.3(\mathrm{~d}, \mathrm{~J}=2.1 \mathrm{~Hz}), 137.8,137.4,136.3,136.2,130.9(\mathrm{~d}$, $\mathrm{J}=8.3 \mathrm{~Hz}), 127.9,126.0,125.9,125.6,43.2(\mathrm{~d}, \mathrm{~J}=28.1 \mathrm{~Hz}$, py $\left.-\mathrm{CH}_{2}\right), 24.9(\mathrm{~d}, \mathrm{~J}=28.1 \mathrm{~Hz}), 21.3,21.0,20.8,1.01\left(\mathrm{PdCH}_{3}\right)$. Anal. Calcd for $\mathrm{C}_{34} \mathrm{H}_{41} \mathrm{CINPPd}$ : C, 64.15; H, 6.49; N, 2.20. Found: C, 64.02; H, 6.22; N, 1.99.

Complex 5b. This complex was prepared according to a procedure similar to that for $\mathbf{5 a}$ : light yellow solids (yield 94.6\%); mp 220-221 ${ }^{\circ} \mathrm{C}$ dec. ${ }^{1} \mathrm{H}$ NMR $\left(\mathrm{CDCl}_{3}, 400 \mathrm{MHz}\right): \delta$ 7.13 (dd, J = 7.7, 7.7 Hz, $1 \mathrm{H}$, py $\left.\mathrm{H}_{4}\right), 7.41-7.28(\mathrm{~m}, 5 \mathrm{H}, \mathrm{Ar} \mathrm{H}$, py $\mathrm{H}), 7.09-7.00\left(\mathrm{~m}, 5 \mathrm{H}, \mathrm{Ar} \mathrm{H}\right.$, py H), $6.81\left(\mathrm{~s}, 2 \mathrm{H}, \mathrm{Ar} \mathrm{H}_{3,5}\right)$, $4.29\left(\mathrm{~d}, \mathrm{~J}=9.8 \mathrm{~Hz}, 2 \mathrm{H}, \mathrm{CH}_{2}\right), 2.70\left(\mathrm{~s}, 6 \mathrm{H}, \mathrm{Ar}-\mathrm{CH}_{3}\right), 2.26(\mathrm{~s}$, $\left.3 \mathrm{H}, \mathrm{Ar}-\mathrm{CH}_{3}\right), 1.74\left(\mathrm{~s}, 6 \mathrm{H}, \mathrm{Ar}-\mathrm{CH}_{3}\right), 0.80(\mathrm{~d}, \mathrm{~J}=3.2 \mathrm{~Hz}, 3 \mathrm{H}$, $\left.\mathrm{PdCH}_{3}\right) .{ }^{31} \mathrm{P}$ NMR $(161.9 \mathrm{MHz}): \delta 29.4 .{ }^{13} \mathrm{C} \mathrm{NMR}(100 \mathrm{MHz}):$ $\delta 163.2,156.4,143.2(\mathrm{~d}, \mathrm{~J}=12.7 \mathrm{~Hz}), 137.8(\mathrm{~d}, \mathrm{~J}=5.7 \mathrm{~Hz})$, 136.1, $132.0(\mathrm{~d}, \mathrm{~J}=8.6 \mathrm{~Hz}), 131.8(\mathrm{~d}, \mathrm{~J}=6.5 \mathrm{~Hz}), 131.2(\mathrm{~d}, \mathrm{~J}$ $=2.2 \mathrm{~Hz}), 128.1,126.4,126.3(\mathrm{~d}, \mathrm{~J}=8.6 \mathrm{~Hz}), 125.3,124.8$, $38.0\left(\mathrm{~d}, \mathrm{~J}=30.0 \mathrm{~Hz}, \mathrm{py}-\mathrm{CH}_{2}\right), 22.2(\mathrm{~d}, \mathrm{~J}=9.6 \mathrm{~Hz}), 21.3,20.3$, $1.2\left(\mathrm{PdCH}_{3}\right)$. Anal. Calcd for $\mathrm{C}_{30} \mathrm{H}_{33} \mathrm{PNCIPd}$ : C, 62.08; $\mathrm{H}, 5.73$; N, 2.41. Found: C, 62.29; H, 5.75; N, 2.30.

Complex 6a. To a mixture of $5 \mathrm{a}(0.16 \mathrm{~g}, 0.25 \mathrm{mmol})$ and $\mathrm{AgBF}_{4}(0.049 \mathrm{~g}, 0.25 \mathrm{mmol})$ in a $25 \mathrm{~mL}$ flask was added dichloromethane $(10 \mathrm{~mL})$ and acetonitrile $(0.5 \mathrm{~mL})$ with stirring. The reaction mixture was filtrated through Celite to remove the silver salt, and the filtrate was concentrated. The residue was dissolved in ether for crystallization. Compl ex $\mathbf{6 a}$ was obtained as an aqua complex as light yellow crystalline solids (yield $0.18 \mathrm{~g}, 98 \%$ ): $\mathrm{mp} 166-168{ }^{\circ} \mathrm{C}$ dec. ${ }^{1 \mathrm{H}} \mathrm{NMR}$ $\left(\mathrm{CDCl}_{3}, 400 \mathrm{MHz}\right): \delta 7.74\left(\mathrm{~d}, \mathrm{~J}=7.6,7.6 \mathrm{~Hz}, 1 \mathrm{H}, \mathrm{py} \mathrm{H}_{4}\right), 7.32$ $\left(\mathrm{d}, \mathrm{J}=7.6 \mathrm{~Hz}, 1 \mathrm{H}\right.$, py $\left.\mathrm{H}_{3}\right), 7.05(\mathrm{~d}, \mathrm{~J}=7.6 \mathrm{~Hz}, 1 \mathrm{H}$, py $\left.\mathrm{H}_{5}\right), 6.95(\mathrm{~s}, 2 \mathrm{H}, \mathrm{Ar} \mathrm{H}), 6.84(\mathrm{~d}, \mathrm{~J}=3.8 \mathrm{~Hz}, 4 \mathrm{H}, \mathrm{Ar} \mathrm{H}), 4.49(\mathrm{~d}$, $\left.\mathrm{J}=11.4 \mathrm{~Hz}, 2 \mathrm{H}, \mathrm{CH}_{2}\right), 2.46\left(\mathrm{~s}, 12 \mathrm{H}, \mathrm{Ar}-\mathrm{CH}_{3}\right), 2.33(\mathrm{~s}, 3 \mathrm{H}$,

$\left.\mathrm{Ar}-\mathrm{CH}_{3}\right), 2.23\left(\mathrm{~s}, 6 \mathrm{H}, \mathrm{Ar}-\mathrm{CH}_{3}\right), 2.0\left(\mathrm{~s}, 2 \mathrm{H}, \mathrm{H}_{2} \mathrm{O}\right), 1.98(\mathrm{~s}, 6 \mathrm{H}$ $\left.\mathrm{Ar}-\mathrm{CH}_{3}\right), 0.35\left(\mathrm{~d}, \mathrm{~J}=2.5 \mathrm{~Hz}, 3 \mathrm{H}, \mathrm{PdCH}_{3}\right) .{ }^{31} \mathrm{P}$ NMR $(161.9$ $\mathrm{MHz}): \delta$ 11.9. ${ }^{13} \mathrm{C}$ NMR $(100 \mathrm{MHz}): \delta 160.9,156.9,142.4(\mathrm{~d}$, $\mathrm{J}=10.8 \mathrm{~Hz}), 139.8,136.5,133.1(\mathrm{~d}, \mathrm{~J}=19.4 \mathrm{~Hz}), 132.4,132.3$, 128.5, $126.8(\mathrm{~d}, \mathrm{~J}=10.4 \mathrm{~Hz}), 125.7,123.6(\mathrm{~d}, \mathrm{~J}=8.4 \mathrm{~Hz}), 38.4$ $\left(\mathrm{d}, \mathrm{J}=8.8 \mathrm{~Hz}, \mathrm{py}-\mathrm{CH}_{2}\right), 22.3(\mathrm{~d}, \mathrm{~J}=8.8 \mathrm{~Hz}), 21.1,2.7\left(\mathrm{PdCH}_{3}\right)$. Anal. Calcd for $\mathrm{C}_{36} \mathrm{H}_{44} \mathrm{~N}_{2} \mathrm{PPdBF}_{4}$ : C, 57.85; $\mathrm{H}, 6.14 ; \mathrm{N}, 1.98$. Found: $\mathrm{C}, 57.48 ; \mathrm{H}, 6.14 ; \mathrm{N}, 2.33$.

Complex $\mathbf{6 b}$. The procedure for the preparation of this compound is similar to that for $\mathbf{6 a}$ : yellow solids (yield $97 \%$ ); $\mathrm{mp} 174-175^{\circ} \mathrm{C}$ dec. ${ }^{1} \mathrm{H}$ NMR $\left(\mathrm{CDCl}_{3}, 400 \mathrm{MHz}\right): \delta 7.91$ (dd, $\mathrm{J}=7.7,7.6 \mathrm{~Hz}, 1 \mathrm{H}$, py $\left.\mathrm{H}_{4}\right), 7.81\left(\mathrm{~d}, \mathrm{~J}=7.7 \mathrm{~Hz}, 1 \mathrm{H}\right.$, py $\left.\mathrm{H}_{3}\right)$, 7.43-7.17 (m, 8H, Ar H), 7.07 (d, J = 7.6 Hz, $1 \mathrm{H}$, py $\left.\mathrm{H}_{5}\right)$, $6.81(\mathrm{~s}, 2 \mathrm{H}, \mathrm{Ar} \mathrm{H}), 4.43$ (d, J $\left.=11.1 \mathrm{~Hz}, 2 \mathrm{H}, \mathrm{CH}_{2}\right), 2.62(\mathrm{~s}, 6 \mathrm{H}$, $\left.\mathrm{Ar}-\mathrm{CH}_{3}\right), 2.30\left(\mathrm{~s}, 3 \mathrm{H}, \mathrm{Ar}-\mathrm{CH}_{3}\right), 2.01\left(\mathrm{~s}, 3 \mathrm{H}, \mathrm{CH}_{3} \mathrm{CN}\right), 1.76(\mathrm{~s}$, $\left.6 \mathrm{H}, \mathrm{Ar}-\mathrm{CH}_{3}\right), 0.48\left(\mathrm{~d}, \mathrm{~J}=2.1 \mathrm{~Hz}, 3 \mathrm{H}, \mathrm{PdCH}_{3}\right) .{ }^{31} \mathrm{P} \mathrm{NMR}(161.9$ $\mathrm{MHz}): \delta 32.9 .{ }^{13} \mathrm{C} N M R(100 \mathrm{MHz}): \delta 161.0,156.9,142.4(\mathrm{~d}$, $\mathrm{J}=14.9 \mathrm{~Hz}), 139.9,138.9,136.5,133.1(\mathrm{~d}, \mathrm{~J}=9.7 \mathrm{~Hz}), 132.3$ $(d, J=5.4 \mathrm{~Hz}), 128.4,126.8(\mathrm{~d}, \mathrm{~J}=10.4 \mathrm{~Hz}), 125.7,123.7(\mathrm{~d}$, $\mathrm{J}=9.0 \mathrm{~Hz}$ ), $38.4\left(\mathrm{~d}, \mathrm{~J}=32.3 \mathrm{~Hz}, \mathrm{py}-\mathrm{CH}_{2}\right), 22.3(\mathrm{~d}, \mathrm{~J}=8.9$ $\mathrm{Hz}), 21.1,19.9,2.6\left(\mathrm{CH}_{3} \mathrm{CN}\right), 1.5\left(\mathrm{PdCH}_{3}\right)$. Anal. Calcd for $\mathrm{C}_{32} \mathrm{H}_{36} \mathrm{PN}_{2} \mathrm{PdBF}_{4}$ : $\mathrm{C}, 57.12 ; \mathrm{H}, 5.39 ; \mathrm{N}, 4.16$. Found: $\mathrm{C}, 57.54$; $\mathrm{H}, 5.46 ; \mathrm{N}, 4.00$.

Complex 10a. A mixture of $3 a(0.10 \mathrm{~g}, 0.208 \mathrm{mmol})$ and (DME) $\mathrm{NiBr}_{2}$ in $\mathrm{CH}_{2} \mathrm{Cl}_{2}(5 \mathrm{~mL})$ was stirred at room temperature for $14 \mathrm{~h}$. U pon concentration, the crude product was recrystallized from dichloromethane/ether to give the desired complex as light brown solids (yield $133 \mathrm{mg}, 92 \%$ ): $\mathrm{mp} 190-192{ }^{\circ} \mathrm{C}$ dec. $\lambda_{\max }=498.5 \mathrm{~nm}(\epsilon=138) .{ }^{1} \mathrm{H} \mathrm{NMR}\left(\mathrm{CDCl}_{3}, 400 \mathrm{MHz}\right): \delta$ 7.23 (br), $4.98(\mathrm{br}), 2.14(\mathrm{br}), 1.6-0.84(\mathrm{br}) .{ }^{31} \mathrm{P} \mathrm{NMR}\left(\mathrm{CDCl}_{3}\right.$, $161.9 \mathrm{MHz}$ ): $\delta-8.9(\mathrm{br})$. Anal. Calcd for $\mathrm{C}_{33} \mathrm{H}_{38} \mathrm{Br}_{2} \mathrm{NNiP}$. $3 / 2 \mathrm{CH}_{2} \mathrm{Cl}_{2}$ : C, 50.20; $\mathrm{H}, 5.01$. Found: C, 50.05; $\mathrm{H}, 5.00$.

Complex 10b. Procedures for preparation of this compound are similar to those for 10a: dark-brown solids (yield 88\%); $\mathrm{mp} 182-184^{\circ} \mathrm{C}$. Unlike $7 \mathbf{a}$, no NMR data were recorded due to the paramagnetic nature of 10b. $\lambda_{\max }=498.5 \mathrm{~nm}(\epsilon=100)$. Anal. Calcd for $\mathrm{C}_{29} \mathrm{H}_{30} \mathrm{Br}_{2} \mathrm{NN}$ IP: C, 54.25; $\mathrm{H}, 4.71$. Found: $\mathrm{C}$, 54.05; H, 4.62.

Crystallography. Crystals suitable for X-ray determination were obtained for $\mathbf{5 b}, \mathbf{6 a}, \mathbf{6 b}, \mathbf{1 0 a} \cdot{ }_{3} / \mathrm{CH}_{2} \mathrm{Cl}_{2}$, and $\mathbf{1 0 b}$ by slow diffusion of hexane into a dichloromethane solution at room temperature. Cell parameters were determined on a Siemens SMART CCD diffractometer. Crystal data of these complexes are listed in Table 5, and ORTEP plots of $\mathbf{5 b} \mathbf{b} \mathbf{6 b}$, and $\mathbf{1 0 a}$ are shown in Figures $1-3$, respectively (labels of phenyl groups are omitted for clarity). Other crystallographic data are deposited as Supporting Information. 
Acknowledgment. We thank the National Science Council for financial support (Grant No. NSC92-2113M-002-040).

Supporting Information Available: Complete description of the X-ray crystallographic structure determinations of $\mathbf{5 b}, \mathbf{6 a}, \mathbf{6 b}, \mathbf{1 0 a} \cdot 3 / 2 \mathrm{CH}_{2} \mathrm{Cl}_{2}$, and $\mathbf{1 0 b}$, including ORTEP plots of $\mathbf{6 a}$ and $\mathbf{1 0 b}$ and tables of atomic coordinates, isotropic and anisotropic thermal parameters, and bond distances and angles. This material is available free of charge via the Internet at http://pubs.acs.org.

OM030242 